\title{
The Effect of E-Service Quality on Online Customer Satisfaction in Nigeria: A Study of Deposit Money Banks
}

\author{
Osagie Leslie Uwabor Ph.D \\ Federal College of Education (Technical), \\ School of Business Education, Department of Marketing, Omoku, Rivers State. Nigeria \\ P.M.B 488 Uniport Post Office, Port Harcourt Nigeria \\ Okoroafor Chimaeze Ph.D \\ Michael Okpara University of Agriculture \\ College of Management Sciences, Department of Marketing, Umudike Abia State,Nigeria \\ Ezenta, Ogemdi Nneoma Ph.D \\ University of Nigeria - Enugu Campus, Faculty of Business Adminstration, Department of Marketing, Nigeria
}

\begin{abstract}
The study examined effect of Electronic Service Quality on online Customer satisfaction in Deposit Money Banks in Nigeria. Its aim was to assess the level of relationship between e-service quality and customer satisfaction of deposit money banks in Nigeria. In line with the objective of the study, four null hypotheses were formulated to guide the research. The theoretical foundation of the study was based on resource base and sustainable theories. The study adopted quasi-experimental research design. The population size was drawn from the customer of quoted deposit money banks with international authorization in Nigeria. A sample size of 384 customers was obtained using Krejcie and Morgan formula. A probability simple random sampling technique was further utilized in picking the respondents. A questionnaire of five point likert scale was used in data collection. Frequency, percentages, bar and pie charts were used in analysing both the demographic data of the respondents, mean and standard deviation to answer research questions, while Spearman rank order correlation coefficient was employed in testing the hypotheses formulated for the study. All the null hypotheses were rejected. The research therefore revealed that; a significant relationship exist between customization and repurchase intension, customization and referral, customer support and repurchase intention, customer support and referral of deposits money bank in Nigeria. It was concluded that, when the quality of e-service is improved in deposit money banks; it increases customer satisfaction. It was therefore recommended amongst others that, online banking applications should be made easier for customers to make use of. The websites should be developed to suit individual needs; more awareness and sensitization programmers' should be given to customers on the need for e-service banking. The benefits should be emphasized continuously.
\end{abstract}

Keywords: Electronic, Service, Quality, Online, Customer, Satisfaction, Deposit, Money, Bank

DOI: $10.7176 / \mathrm{JMCR} / 82-03$

Publication date:September $30^{\text {th }} 2021$

\section{Introduction}

Customers are presumed to be one of the most critical stakeholders in any business organization because, without the customers, organizations are not likely to succeed. Knowledge of consumer behaviour will go a long way in ensuring effective marketing policies towards the interest of customers which will eventually facilitate positive customer attitude towards the organisations. More especially, since customer behavioural intention is a strong indication of his actual behaviour.

E-service is becoming more critical for companies to retain and attract customers. What brings online customers back to the company's websites is a sense of loyalty that comes from good services offered by companies. Effective e-service quality in banking is one of the most important ways to keep customers coming back despite the hurdles in the Nigeria banking sector. The strategies to maintain customers confidence includes responding to customers' complaints in a thorough and timely manner and interacting with customers through face to face meeting, telephone, mail, fax and email. Above all, bank employees involve themselves in some aspect of customer service. Washburn Financial Services explain that in increased competition, banks are required to become more and more customer-focused. It is costly to get new customers than to retain old customers. Keeping customers requires customer service staff in banks to be mature and intelligent. Banking has ceased to be an entirely armchair profession largely directed by conservative men stripped of initiatives. In today's world, banking is structured by innovative identification of the needs of the customers. Effective customer service is the process by which an organisation delivers its services or products in a way that allows the customer to access them in the most efficient, fair, cost-effective and humanly satisfying and pleasurable manner possible.

This significant contribution of the services industry and specifically the banking sector in Nigeria warrant 
investigation in order to enhance the sector's continuous growth which will eventually result in the better performance of the economy. However, it is important to note that one of the ways through which banks can meet the expectations of their customers who are the anchor of the banks' business is via the understanding of the customers' behaviour.

Base on the relevance of e-service quality for retaining customer loyalty, researchers have empirically investigated this area of study. For instance, Sohn and Tadisina (2008) studied "Development of e-service quality measure for the Internet-based financial institutions. Lin and Lee (2005) examined "Customer perceptions of eservice quality in online shopping. Osagie and Geraldine (2020), examined E-service Quality and Customer Loyalty in Deposit Money Banks. There are very few scholarly inquiries that simultaneously measure e-service quality against online customer satisfaction in deposit money banks. Therefore, this study attempts to bridge such knowledge gaps. Thus, this study offers a more holistic framework of two dimensions of e-service quality and isolated the effect of each on the measures of customer satisfaction. Our point of departure is, therefore, to empirically investigate the effect of e-service quality on online customer satisfactions in deposit money banks using Nigeria as our case study.

\section{Statement of the Problem}

The banking industry has been characterised by the emergence of different channels of banking such as Internet banking, Automated Teller Machines (ATM), phone banking, mobile banking and global competition that are forcing bankers to explore the importance of customer satisfaction and maintaining long term relationships with customers. Banks management needs to develop strategies that will give them competitive advantage and differentiate them from their competitors. Competitive advantage can be created through the delivery of higheservice quality. E-service quality has been proven to lead to customer loyalty (Caruana, 2002). Excellence in eservice quality is a key to achieve customer satisfaction which is the primary goal of business organisations, due to the advantages of customer retention (Ehigie, 2006).

Salem \& Rashid (2011), in their study concluded that customer satisfaction has not been explicitly studied for banking sector firms for technology adoption called for an informed empirical investigation. Evidence from the literature shows that the quality of services and products enhances customer satisfaction.

Yousaf and Steen (2011), found that e-service quality presence and intensity can predict higher productivity and profits on hotel performance and customer satisfaction. In the light of the above, it is likely that the benefits of the application of electronic service quality in the marketing of bank services could also improve the level of customer satisfaction in deposit money bank. Incidentally, empirical literature in the area of the effect of e-service quality and customer satisfaction of deposit money banks in Nigeria is very scanty due to limited research in this area. Haven discovered this, there is need to fill the knowledge gap in existing literature.

Given the uncertainty of electronic service quality and the problem of online customer satisfaction in the banking industry, this study seeks to ascertain the extent to which e-service quality has affects online customer satisfaction of banks.

It is against this backdrop that the researchers investigate the effect of e-service quality on online customer satisfaction in deposit money banks in Nigeria.

\section{Objectives of the Study}

This study focuses on determining the relationship between the effect of e-service quality and customer satisfaction of deposit money banks in Nigeria. The specific objectives of the study are as follows:

1. To ascertain the extent of relationship between customization and repurchase intention of deposit money banks.

2. To evaluate the relationship between customization and referral of deposit money banks.

3. To assess the relationship between customer support and repurchase intention of deposit money banks.

4. To ascertain the extent of relationship between customer support and referral of deposit money banks.

\section{Research Questions}

The following research questions were derived;

1. To what extent does customization influence repurchase intention of deposit money banks?

2. To what extent does customisation influence referral of deposit money banks?

3. To what extent does customer support influence repurchase intention of deposit money banks?

4. To what extent does customer support influence referral of deposit money banks?

\section{Research Hypotheses}

Derived from the study are the following null hypotheses;

Ho1: There is no significant relationship between customization and referral of deposit money banks

Ho2: There is no significant relationship between customization and repurchase intention of deposit money banks 
Ho3: There is no significant relationship between customer support and repurchase intention of deposit money banks

Ho4: There is no significant relationship between customer support and referral of deposit money banks

\section{Review of Related Literature}

At this point of the study, the researchers focus on the review and discussion of published researched materials relating to e-service quality and customer satisfaction. The review of literature in this study will include an emphasis on the theoretical foundation, conceptual framework and empirical studies carried out on e-service quality and customer satisfaction.

\section{Theoretical Foundation}

This study is established on the resource-based and sustainable theory which is used to determine the strategic resources with the potential to deliver comparative advantage to a firm. The theory explores the relationships between resources, capabilities, competition and profitability (Osagie, Justie \& Ezechirinum, 2019).

The study, therefore, reviewed the following theories and models as a background to evaluating the extent to which e-service quality under study is guided by some of these leading theories and models of customer relationship marketing.

1. Data Envelope Analysis Service Quality Model (Soteriou and Stavrinides, 2000)

2. $\quad$ Evaluated performance and Normalised Quality Model (Teas 1993)

Internal Service Quality Data Envelope Analysis (DEA) Model (Soteriou and Stavrinides, 2000)

According to Soteriou and Stavrinides (2000), service quality is an essential factor that is to consider when assessing a bank branch performance. The branch may report a high volume of products and services offered as well as profits, but lose its long-term advantage owing to eroding service quality. The authors presented a service quality model that can be used to provide directions to a bank branch for optimal utilisation of its resources. The model does not aim to develop the service quality measures. Instead, it guides how such measures are considered for service quality improvements while pointing out poor utilisation of resources. The inputs to the model consist of two sets: consumable resources such as personnel, space, time and the number of accounts in different categories. The output of the model is the level of service quality perceived by the personnel of the branch. The data envelope analysis (DEA) model compares branches on how well they transform these resources (inputs) to achieve their level of service quality (output) given the client base. The DEA model will identify under-performers and suggest ways for their improvement.

The input minimisation DEA model will provide information on how much reduction can occur with consumable resources while delivering the same level of service quality. On the other hand, output maximisation DEA model provides information on how much service quality can be improved using the same consumable resources.

Figure 1.Data Envelope Analysis Service Quality Model

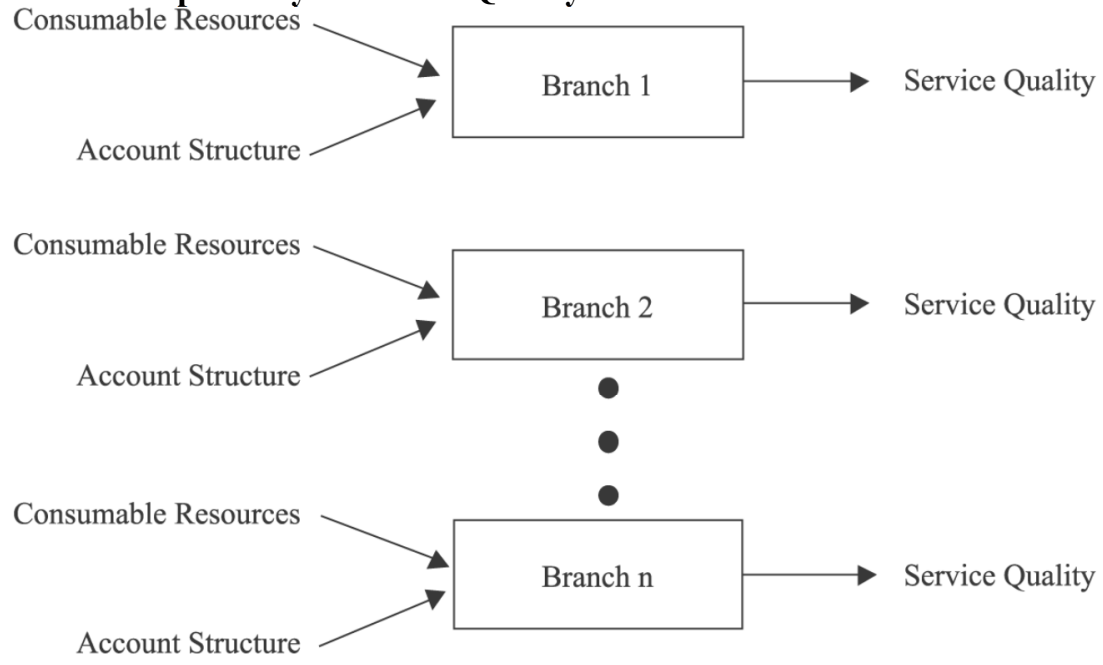

Source: Soteriou and Stavrinides (2000) 
Evaluated Performance and Normalised Quality Model (Teas, 1993)

According to the Teas (1993), the conventional disconfirmation model has conceptual, theoretical and measurement problems. He pointed out the following issues in the measurement of service quality (Parasuraman et al., 1988) as conceptual definition ambiguity; theoretical justification of expectations in the measurement of service quality; the usefulness of the probability specification in the evaluated performance (EP)measurement; and link between service quality and consumer satisfaction and dissatisfaction.

Teas (1993) proposed the following two frameworks for service quality. Evaluated performance (EP) framework: with the assumption that an individual evaluates object I with perceived certainty and that the object I has a constant amount of each attribute. The perceived quality is modelled thus:

Qi $1 / 4-1 \frac{1}{2} \mathrm{Sm}$

$\mathrm{j}^{1 / 41} 1 \mathrm{wjj} ð \mathrm{Ajk}-\mathrm{IjPj}_{-}$

Where:

Qi 1/4The individual's perceived quality of object $i$.

wj $1 / 4$ Importance of attribute $\mathrm{j}$ as a determinant of perceived quality.

Aij $1 / 4$ Individual's perceived amount of attribute $\mathrm{j}$ possessed by objecti.

$\mathrm{Ij} 1 / 4$ The ideal amount of attribute $\mathrm{j}$ as conceptualised in classical ideal point

\section{Attitudinal Models}

$\mathrm{m}^{1 / 4}$ Number of attributes.

Assuming the perceived ability of the product to deliver satisfaction can be conceptualised as the product's relative congruence with the consumer's ideal product features.

\section{Figure 2. Normalised Quality Model}

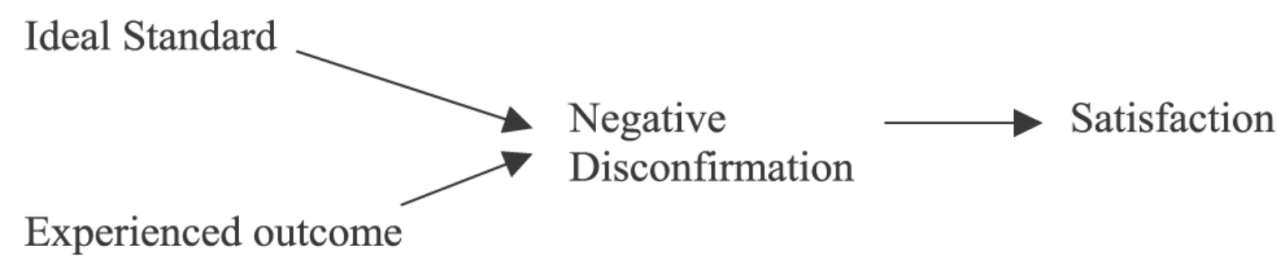

\section{Source: Mattsson (1992)}

\section{Teas 1993}

If the object $i$ is defined as the excellence norm that is the focus of revised SERVQUAL concept, the above equations can be used to define the perceived quality of excellence norm Qe in terms of the similarity between the excellenceValue and attitude in negative disconfirmation norm and the ideal object with respect to " $\mathrm{m}$ " attributes. The quality of another object $i$,

Qi relative to the quality of excellence norm then normalised quality (NQ) is:

NQ $1 / 4$ Q Q 2 Qe

$\mathrm{NQ} 1 / 4$ Normed quality index for object i.

Qe $1 / 4$ the individual's perceived quality of the excellence norm object.

For infinite ideal points, norm quality is:

$\mathrm{NQ}=\sum_{\mathrm{j}=1}^{\mathrm{m}} \mathrm{Wj}(\mathrm{Aij}-\mathrm{Aej})$

$j 1 \frac{1}{4}$ individual's perceived amount of attribute " $\mathrm{j}$ " possessed by the excellence norm "e". 
Figure 3: Conceptual Framework

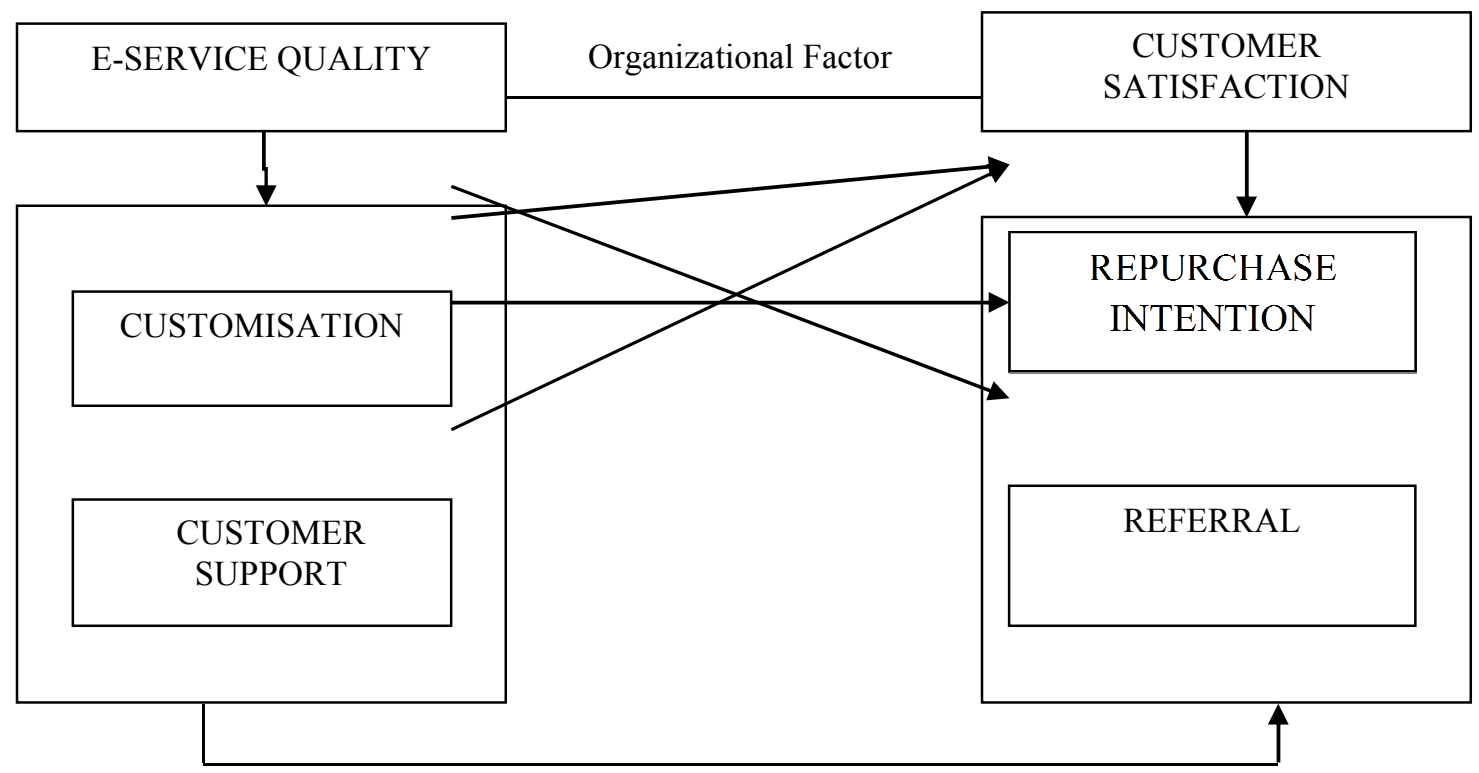

Conceptual Framework of the Relationship between e-service quality and customer satisfaction in deposit money banks in Nigeria.

Source: Osagie and Ugwuonah (2020) and Researchers Concept, 2021.

After detailed reviewed of literature on e-service quality and customer satisfaction of deposit money bank, the researchers came up with the above model of the relationship between e-service quality with dimensions as customization and customer support while customer satisfaction was measured with repurchase intention and referral.

\section{E-Service Quality}

Yang and Jun (2002) posit that E-service quality gained considerable attention in the last decades due to its strong effect on business performance in many aspects such as profitability, lower costs, customer satisfaction and loyalty. Measuring online service quality becomes industry or context-dependent in which it may increase the difficulties to constitute a global measure. A particular domain then is required to define the significant effects of e-service quality. The success of the provided e-services depends significantly on their quality

Typically, online customers can more easily compare alternatives than offline customers,and a competing offer is just a few clicks away on the Internet. Shankar, Smith, and Rangaswamy, (2003) added that online consumers have a wider range of choices in selecting products and services, and highly competitive prices. As a result, competition between different Websites is high in order to attract the users' attention and make them repeat a visit. In this situation, it is generally not easy for online retailers to gain competitive advantages based solely on a cost leadership strategy

The delivery of these electronic services offers benefits for both firms and customers. The use of technology enables the service provider to have a standardised service delivery, reduced labour costs, to expand the delivery options (Curran \& Meuter, 2005) and to improve productivity and convenience for their employees and customers (La \& Kandampully, 2002).

Various conclusions are inferred from the reviewed literature:

(1) E-service quality is a multidimensional construct whose measurement must gather the evaluation of the interaction with the Website, the evaluation carried out by the customer of the product or service received and, if any problem arises, how the Website of the online firm handles it (Collier \& Bienstock, 2006). Although most researchers are in favour of the evaluation of this latter aspect.

(2) There are two approaches when tackling the conceptualisation and measurement of e-service quality. The first approach is the technical characteristics of the Website (technical quality). The earlier studies about Internet service quality belong to this first group. They centred uniquely on the interaction that takes place between the customer and the Website. None of these research works gathers all the aspects of the online purchasing process and therefore they do not carry out a complete evaluation of e-service quality. The main proposal of these measurement instruments is to generate information for the site designers, more than measuring the quality of the service which customers perceive (Parasuraman et al., 1985). This weakness is the primary motive for the appearance of the second approach (service quality) which offers 
a complete vision of the field of the e-service quality construct. The dimensions and the measurement instruments gather not only the technical aspects of the Website but also how the customers perceive the quality of the product or service received and how their problems or doubts solved during the service provision.

(3) The evaluation of e-service quality is carried out at different levels of abstraction depending on the study. Most researchers offer a set of dimensions (first-order constructs) and a series of indicators to measure each of them ( $\mathrm{Ho} \&$ Lee, 2007). However, other authors propose second-order hierarchical models (Wolfinbarger \& Gilly, 2003), or even third order models (Fassnacht \& Koese, 2006).

\section{Dimensions of E-Service Quality \\ Customization}

Over the past decades, there has been a growing recognition among scholars and practitioners that product and service differentiation represents a source of competitive advantage. The core idea of differentiation is to identify profitable market segments and to design products and services to satisfy the needs of the target segments optimally. As a more extreme form of differentiation, the concept of customisation - that means the degree to which the firm's offering is tailored to meet heterogeneous customers' needs (Anderson, Fornell, \& Rust, 1997). Customization aims at satisfying as many needs as possible for each customer, in contrast to conventional techniques, which try to reach as many customers as possible while satisfying a somewhat limited number of customer needs (Fiore, Lee \& Kunz, 2004)

The term customisation refers to the adaption of a product or service according to specific customer needs (Kotler \&Armstrong, 2011). It allows them to match their offerings with customer needs better, fosters customer satisfaction and loyalty, and potentially leads to increased delivery performance and profit (Fornell, Johnson, Anderson, Cha \& Bryant, 1996).

In recent years, researchers and practitioners have paid increasing attention to the concepts of customisation. Customizing products is not a recent invention, one might think of custom-fit suits tailored for centuries. However, developments in manufacturing systems enable the mass production of customised products. Moreover, the increasing digitalisation and engagement of customers in Social Media support the dialogue between companies and customers in order to discover individual needs and wishes (Sashi, 2012).

Examples of customisation are the selective placement of product propositions for individual customers on webpages ,e.g. Amazon (also known under the term predictive personalisation) or the possibility to configure products during the buying process by the customer, as it is possible for automobiles or clothing items (Garcia \& Winkelhues, 2016). In a broader sense, the above example refers to the participation of the customer within the design process. In this context, the relation between customisation and customer satisfaction, customer loyalty as well as the brand assessment has drawn increasing research attention.

Customisation - especially when customers play an active role is of particular interest concerning satisfaction and loyalty. Through customisation, products or services inherit a personal character for the customer; the emotional bond is, therefore, stronger (Sashi, 2012). The assumption is, that customised products increase satisfaction and thus indirectly also loyalty, i.e. repurchasing behaviour. Studies support this statement: Concerning services it is discovered that personalised offers correlate with a higher level of satisfaction as well as an increased customer loyalty (Bock, Mangus \& Garretson, 2016; Coelho \& Henseler, 2012).

\section{Customer Support}

Customers are the heart of every successful business and therefore businesses need to be more concentrated on customers than more ever. Except those who donate blood voluntarily, one is either selling a service or a product for a living. Politicians, bankers, clerks, messengers, bus conductors, ticket agents, market women and everyone who provides a trade or service has a customer. According to Scott (2002), Customer support service is a series of activities designed to enhance the level of customer satisfaction, that is, the feeling that a product or service has met the customer expectation. The level of satisfaction can also vary depending on other options the customer may have and other products against which the customer can compare the organisation's products.

In today's business world customer support has become one of the significant functions for every company. The recent competitive market has compelled feel necessity to every company either service provider or manufacturing based company, almost all of them are offering customer support in their marketing practices. Regardless of the numerous presence of such a service, though understanding of how customers' involvement its use in their relations with companies is vague. Service can merely be a general matter or considered as companyspecific (Edvardsson, Enquist \& Johnston, 2005; Lovelock \& Gummesson, 2004).

Goffin and New (2001) explained that customer support service is seen as product support, added value, and after-sales service. For every service provider, customer support is compulsory in order to achieve customers satisfaction which also spotlighted by many researchers (Athaide, Meyers \& Wilemon,1996; Cespedes, 1995; Teresko, 1994). Customer support provides a competitive advantage over other homogeneous products and 
services (Goffin, 1998)

Companies are increasingly looking to customer support as a potential source of competitive advantage to win market share. In this technological revolutionary era,it is hard to use every appliance without the support of technical persons and to reduce this gap of knowledge regarding products almost every company are emphasising more on customer support, thus playing a vitalrole in high technology based company (Goffin, 1994; Lawless \&Fisher, 1990).Excellent customer support is essential for succeeding customer satisfaction. It can increase the success rate of services and can directly contribute to competitive advantage.

Different kind of Technical developments in telecommunications have shifted the attention of many customers towards the service providers, as a result of these companies have established a separate support system department and call centre. However, core service is still substantial because this is the reason for customers to contact customer support service (Roos \& Edvardsson, 2008).

Some of the main challenges in customer service in banking includes a poordatabase, management of customers, illiteracy level of the majority of customers, lack of adequate infrastructure and technology on which customer satisfaction depends on like electricity (for ATM operations) and low level of internet penetration. The importance of technology in banking became obvious when developed countries that had involved IT in its banking operations managed to reduce their costs of operations (Daily Graphic, 2008). Banks in Ghana gradually introduced technology into its operations in the late 1980s to enhance their operations and to help clients enjoy their services with great convenience. Various researches have indicated that technology influences banking in a positive way regarding productivity, cashiers' work, banking transactions, bank patronage, bank services delivery and customers' services (e.g. Idowu, Alu \& Adagunodo 2002; Yasuharu 2003).

\section{Customer Satisfaction}

A cognitive model for characterizing antecedents and consequences of satisfaction was developed by Oliver in 1980; customer satisfaction has been widely developed in both theory and practice (Oliver 1980). Gremler (1995) defined Satisfaction as a mindset stemming from disconfirmed expectation together with emotions resulting from previous experience of customer (Gremler, D.D., 1995). So satisfaction can be considered as a result of regular assessment of experience one having with a product or service in relation to purchase and consumption of it. Here satisfaction can be considered as favorable feeling of customer associated with banks electronic services as a result of the customer dealings with it.

Customer satisfaction has historically been identified in the previous literature, as the critical concept in shaping loyalty (Anderson \& Mittal, 2000; Eriksson \& Vaghult, 2000). It is commonly believed that satisfied customers are more likely to display loyalty behaviour, i.e. repeat purchase and willingness to refer others with positive word of mouth (Bennett \& Rundle -Thiele, 2004; Schultz, 2005). The importance of e-loyalty and esatisfaction, and the close relationships among them have also been a critical issue in the study of e-commerce (e.g., Park \& Kim, 2003; Yang \& Peterson, 2004).

In previous studies, e-satisfaction has been determined to influence e-loyalty. Anderson \& Srinivasan (2003) emphasized the impact of satisfaction on e-loyalty and noted that a satisfied customer is more likely to build a closer relationship with the online retailer.

\section{Measures of Customer Satisfaction \\ Repurchase Intentions}

The concept of repurchase and the factors influencing it has been investigated by many scholars (Mittal \& Kamakura 2001; Quick \& Burton 2000; Wanke \& Fiese 2004). Repurchaseis a consumer's actual behaviour resulting in the purchase of the same product or service on more than one occasion.

Repurchase intention refers to the probability or willingness of consumers who already completed an initial purchase and continues to use and buy from same website or company at a later time under consideration of present and possible situations (Hellier, Geursen, Carr, \& Rickard, 2003; Kuan, Bock \&Vathanophas, 2008). There are several terms similar to repurchase intention such as repeat purchase intention, rebuying intention, re-patronage intention, continuance intention, return intention, and revisit intention (Al - Maghrabi, Dennis, Halliday\& Ali, 2011; Argyriou, 2012).

However, under the condition that consumers have the abilities or resources, consumers are more likely to conduct actual repurchase behaviour when they have stronger repurchase intention. Prior experience from the past transaction such as price consideration, relationship, competition, and performance criteria will influence consumers' willingness to perform a repeat purchase (Li \& Hong, 2013). Li and Hong (2013) mentioned that consumers' repurchase intention is affected by confirmation and satisfaction. According to Jiang and Rosenbloom (2005), consumers with higher satisfaction tend to:

(1) Engage in repeat purchase activities;

(2) Contribute higher revenue to the company with higher consumption amount;

(3) Recommend to friends and families; 
(4) Less likely to switch to competitors simply due to the incentive offered by the competitors.

Besides, consumers will reduce their price sensitivity and are willing to pay higher prices when they are satisfied with the products or services that fulfil their requirements (Hill \&Alexander, 2000). In the highly competitive market, defensive marketing strategy plays a pivotal role to alleviate the possibility of consumers exit, switching and consumers' retention is more important than attracting new consumers because the cost incurred to retain the current consumers is lower than gaining new consumers(Pfeifer, 2005).

The measurement of repurchase intention can help a company to understand whether they can retain consumers and remind the company to improve their consumer retention strategy if the repurchase intention is not of the desired target of a company. The majority of consumers' purchases are potential repeat purchases (Peyrot\& Van Doren, 1994). Customers buy similar products repeatedly from similar sellers, and most purchases represent a series of events rather than a single isolated event. Retention is another common term for repurchase (HennigThurau 2004), which is considered to be one of the most important variables in relationship marketing (Fullerton, 2003). While repurchase is the actual action, repurchase intent is the customer's decision to engage in future activities with the retailer or supplier (Hume, Mort \& Winzar, 2010).

In a competitive business environment, maintaining customer repurchase intention and avoiding significant switching behaviour to sustain operations and gain competitive advantage is very important and the cost of attracting a new customer is as many times as preserving current customers (Kuo \& Yang, 2013). In addition, Chang and Wang (2014) opine that the process of keeping an old consumer is easier than getting a new one, in line with this discovery companies would like to keep the relationship with old consumers and hope to increase their repurchase intention.

The repurchase intention represents three types of purchases: trial purchases, repeat purchases, and long-term commitment purchases (Osagie \& Ugwuonah, 2020).From another side, the formation of customer repurchase intention is no doubt a complicated process, therefore; firm's managers are interested in understanding how an individual's intention to repurchase is formed theoretically and what factors influence such a process empirically (He \& Song, 2008).

There are many definitions for repurchase intention concept depending on different scholars' views. In service context, repurchase intention is defined as the individual's judgment about buying a designated service again from the same company, taking into accounts his current situation and likely circumstances (Hellier, Guersen, Carr and Richard 2003). From behavioural view, Seiders, Glenn, Voss and Andrea (2005) define repurchase intentions as the customer's self-reported likelihood of engaging in future repurchases behaviour. From the online purchasing view, repurchase intention refers to the subjective probability that an individual will Continue to purchase products from the online vendor or store in the future (Chiu \& Solarek, 2009).

Repurchase intention, from customer view, may be the result of customer attitude and commitment towards repurchasing a particular product (Akbar, 2009 cited in Abdul Samad, 2014).

\section{Referral}

Word of mouth, and more specifically customer-initiated referrals originate from current or former customers freely advocating their satisfaction or dissatisfaction with their purchase or experience whereas traditional marketing activities may stimulate word of mouth (Trusov, Bucklin \& Pauwels, 2009).Referral marketing describes the strategic method of maximizing word of mouth in order to promote products or services to potential buyers. To achieve that, marketers encourage, inform and reward customers with financial or non-financial incentives (Buttle, 1998).

As early as1998, Buttle stated that growing number of product and service providers pro-actively try to intervene in the natural process of Word Of Mouth in order to stimulate and manage it more effectively (Buttle, 1998). After following the referral marketing method of a German bank, the conclusion drawn shows that referred buyers were not only more profitable and loyal than regularcustomers but also had higher retention rates. An example of a financial referral marketing case with a financial incentive is given by the Israeli telephone company GolanTelecom which applied a network marketing strategy by providing a financial reward to customers for bringing new clients. In only a few months' time, the company reached over 25,829 new clients, all suggested by related contacts, (GolanTelecom, Annual Report, 2013).

Kumar and Shah (2004) revealed that personal referrals have a powerful effect on consumers. They further said that marketing researchers, using the term "word-of-mouth," have studied the impact of references for decades and those researchers' credits interpersonal communication with far greater influence over consumer attitudes and behaviour than either conventional advertising or neutral print sources, and that the value of personal referrals can constitute a significant portion of a customer's value.

A number of papers in the marketing literature explore word-of-mouth communication as a signalling game in which consumers learn about the quality of a product through friends, and the firm tries to manipulate the information consumers receive, either through hired "trendsetters" (Chatterjee \& Dutta, 2014) or launch strategies (Campbell, 2015). Campbell (2013) studies pricing in the presence of word-of-mouth learning. In particular, the 
medium through which customers communicate with each other has implications both for the cost of making referrals and the value the firm derives from referrals.

Chu and Kim (2011) note that the influence people exert one another through online interactions is different from what is obtained through offline interactions. Burke and Kraut (2014) present evidence from Facebook suggests that one-on-one communication is fundamentally different from multicast communication. The type of interactions one would rely upon to generate referrals will determine the cost, payoff, and network parameters that are primitives in communication model, allowing a comparison between optimal policies using different modes of communication. The firm employs a referral incentive program to expand its customer base and increase profits. When a consumer makes a purchase, he or she is offered a code or a link to share with her friends. When a friend uses that code or link to make a purchase, the original consumer may receive a reward from the firm.

\section{Methodology}

The idea behind this section is to explain, as well as give reasons on the procedures used in collecting and analysing data in this study.

The idea behind this section is to explain, as well as give reasons on the procedures used in collecting and analysing data in this study.

This study adopted Quasi-experimental research design because the elements under study (human beings) are flexible, and are not controlled by the researchers. The cross-sectional survey was also adopted because it relies on a sample of elements from the population of interest measured at a single point. The population was drawn from e-banking customers of quoted deposit money banks with international authorization, in Nigeria because of their involvement in international banking as well as e-service banking. The population of the customers is estimated to be over 4million (Four million) (CBN June 2018). Since the total number of electronic banking customers in Nigeria is above 4 million (CBN, 2018), Krejcie and Morgan (1970) formula was used to determine the sample size of this population which came out to be 384. This study employed the use of frequency and percentages, pie and bar chart in answering research questions and demographic data of the respondents, Spearman rank order correlation coefficient was used in testing the hypotheses formulated for the study, at 0.05 level of significance. This technique (Spearman rank order correlation coefficient) is utilised because it is more effective in determining whether two non-parametric data samples with ties are correlated as well as analysing ordinal data, such as this. The SPSS (version 22) was employed in computing the data.

\section{Result and Discussion \\ Demographic Characteristics}

A total of three hundred and eighty-four (384) copies of questionnaire were distributed to the customers of deposit money bank with international authorization in South-South, Nigeria. Out of three hundred and eighty-four (384) copies of questionnaire distributed in this study, three hundred and sixty-six (366) were returned. This represent $95.31 \%$ rate of return. The researcher discovered that the entire questionnaire returned where correctly filled.

\section{Demographic Data}

Table1 Questionnaire Distribution of Respondents

\begin{tabular}{|l|r|r|r|r|}
\hline & Frequency & Percent & Valid Percent & Cumulative Percent \\
\hline UNION BANK & 25 & 6.8 & 6.8 & 6.8 \\
FIRST CITY MONUMENT BANK & 32 & 8.7 & 8.7 & 15.6 \\
FIRST BANK & 33 & 9.0 & 9.0 & 24.6 \\
ACCESS BANK & 48 & 13.1 & 13.1 & 37.7 \\
SKY BANK & 40 & 10.9 & 10.9 & 48.6 \\
Valid UNITED BANK OF AFRICA & 45 & 12.3 & 12.3 & 60.9 \\
FIDELITY BANK & 30 & 8.2 & 8.2 & 69.1 \\
ZENITH BANK & 21 & 5.7 & 5.7 & 74.9 \\
ACCESS-DIAMOND BANK & 34 & 9.3 & 9.3 & 84.2 \\
GUARANTY TRUST BANK & 58 & 15.8 & 15.8 & 100.0 \\
Total & 366 & 100.0 & 100.0 & \\
\hline
\end{tabular}

From table 1 above, $25(6.8 \%)$ of the questionnaire copies were given to customers of union bank, 32(8.7\%) copies were given to customers of FCMB, 33(9\%) copies were given to first bank customers, 48(13.1\%) copies were given to access bank customers, $40(10.9 \%)$ copies were given to customers of sky bank, $45(12.3 \%)$ copies were given to UBA customers, 30(8.2\%) copies were given to customers of fidelity bank, 21(5.7\%) copies were given to Zenith bank customers, 34(9.3\%) copies were given to access-diamond bank customers, while 58(15.8\%) copies of the questionnaire were given to customers of GTB. 
Fig 1 Percentage distribution of respondents on Gender

\section{Pie chart distribution of respondents on gender}
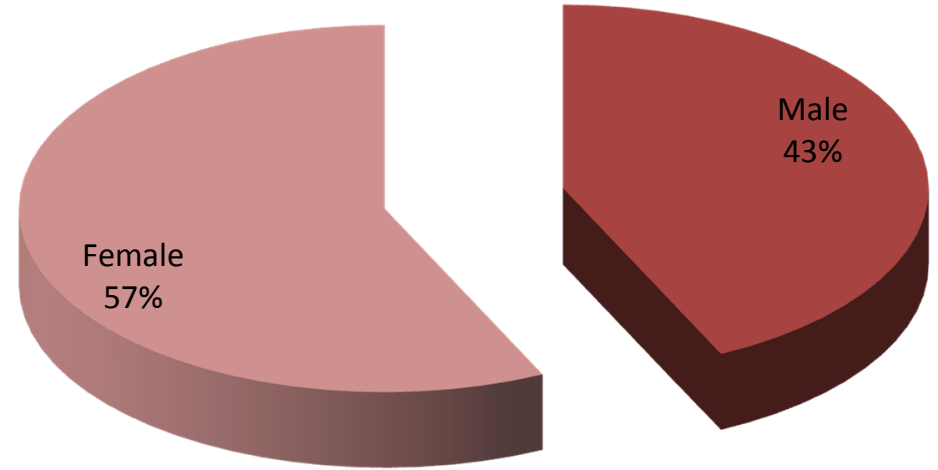

From the above table, $157(43 \%)$ of the respondents were male, while $209(57 \%)$ of the respondents were females.

Fig 2 Percentage distribution of respondents on Age

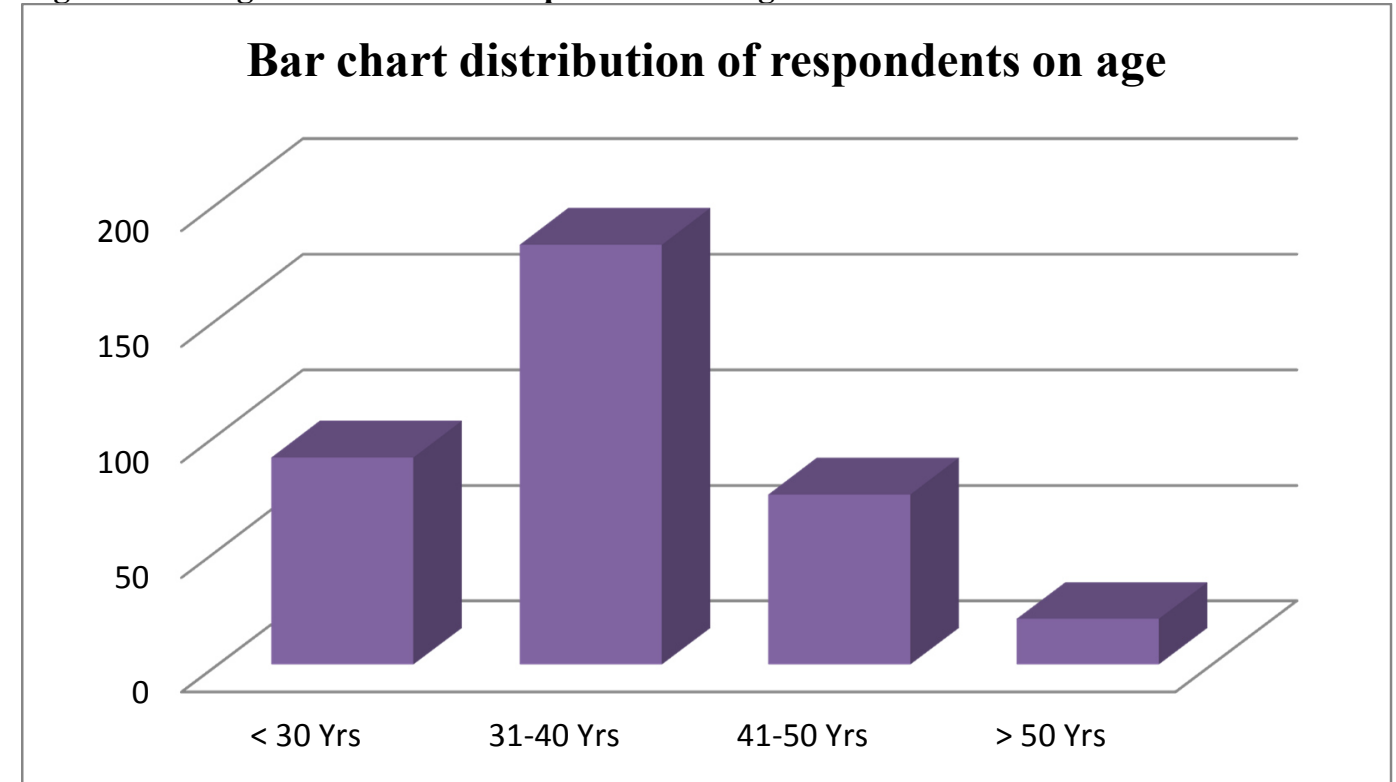

From the above fig 2, 90(25.59\%) of the respondents were less than 30 years of age, $182(49.73 \%)$ of them were between $31-40$ years, $74(20.22 \%)$ of them were between $41-50$ years, while $20(5.46 \%)$ of them were above 50 years of age. 
Fig 3 Percentage distribution of respondents on educational qualification

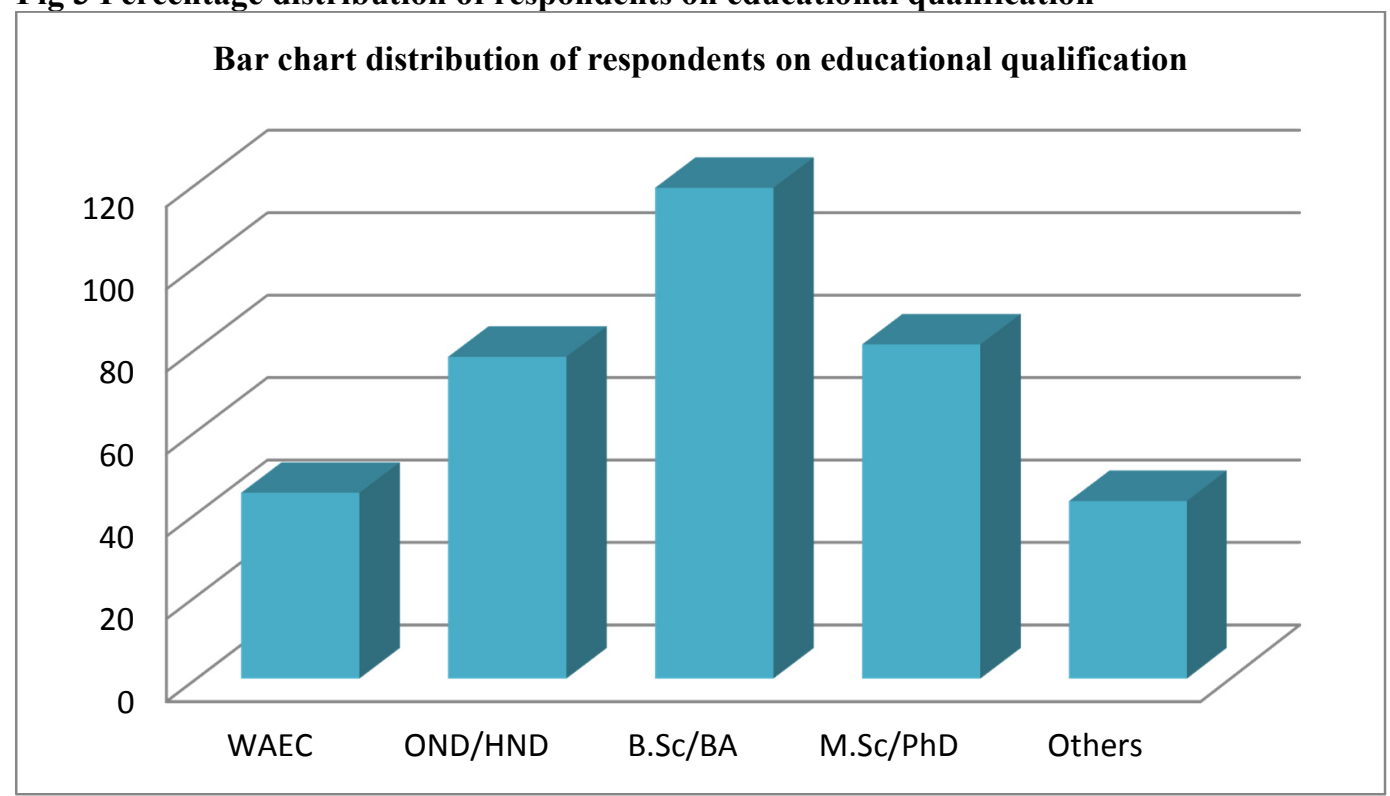

From the above fig 3, 45(12.30\%) of the respondents had WAEC as their highest educational qualification, $78(21.31 \%)$ of them had OND/HND, $119(32.51 \%)$ of them had B.Sc./BA, 81(22.13\%) of them had M.Sc./PhD, while $43(11.75 \%)$ of the respondents had other educational qualification.

Table 2: Mean and Standard Deviation of Responses on Customization Items

\begin{tabular}{|l|r|r|r|}
\hline Items & Mean & $\begin{array}{r}\text { Std. } \\
\text { Deviation }\end{array}$ & $\begin{array}{r}\text { Variance } \\
\hline \text { The website of the bank give personal attention to the bank's online customers }\end{array}$ \\
\hline $\begin{array}{l}\text { Through the e-service platform of the banks, customers are able to carry out e- } \\
\text { banking activities in ways that meets their needs }\end{array}$ & 3.832 & 1.1109 & 1.234 \\
\hline $\begin{array}{l}\text { Bank e-service website usually shows an understanding of the specific needs of } \\
\text { customers }\end{array}$ & 3.594 & 1.0005 & 1.001 \\
\hline $\begin{array}{l}\text { Customers are well satisfied with their bank's e-service channels if it allows } \\
\text { them to perform online transactions without difficulties }\end{array}$ & 3.878 & 1.0108 & 1.095 \\
\hline Customization (CUTM) & 3.6802 & .86042 & .022 \\
\hline
\end{tabular}

\section{Source: Computer Result 2021}

Customization construct was measured using four questionnaire items which were developed on a five point Likert scale. The item labels are shown above. The mean of the four items was calculated to obtain the overall mean response on the customization construct (CUTM). The overall mean response on the items (3.68) shows that the customization on the bank the electronic platform of the banks is judged fairly good. The customers see the platforms as serving the purpose of enabling them to carry out their e-transactions without having many opportunities on personal needs (3.4).

Table 3: Mean and Standard Deviation of Responses on Repurchase Intention Items

\begin{tabular}{|l|r|r|r|}
\hline Items & Mean & $\begin{array}{c}\text { Std. } \\
\text { Deviation }\end{array}$ & Variance \\
\hline $\begin{array}{l}\text { Customers patronise a particular e-service package because it satisfies their } \\
\text { needs }\end{array}$ & 3.734 & 1.0674 & 1.139 \\
\hline $\begin{array}{l}\text { Customers are more interested in a bank that satisfies their e-service needs than } \\
\text { others }\end{array}$ & 4.002 & 1.0360 & 1.073 \\
\hline $\begin{array}{l}\text { Customers consider their bank the first choice whenever they need a professional } \\
\text { banking services }\end{array}$ & 3.944 & 1.0726 & 1.151 \\
\hline $\begin{array}{l}\text { Customers intend to patronize their preferred bank in future whenever the need } \\
\text { arises }\end{array}$ & 4.034 & 1.0079 & 1.016 \\
\hline Repurchase Intention (R1TM) & 3.9293 & .84920 & .721 \\
\hline
\end{tabular}

\section{Source: Computer Result 2021}

Repurchase intention construct was measured using four questionnaire items which were developed on a five point Likert scale. The item labels are shown above. The mean of the four items was calculated to obtain the overall mean response on the repurchase intention construct (RITM). The overall mean response on the items (3.93) shows 
that the customers repurchase intention on their banks electronic platform is judged fairly good. Therefore, customers patronise a particular e-service package not because it satisfies their needs (3.73).

Table 4: Mean and Standard Deviation of Responses on Referral Items

\begin{tabular}{|l|r|r|r|}
\hline Items & Mean & \multicolumn{1}{|c|}{$\begin{array}{c}\text { Std. } \\
\text { Deviation }\end{array}$} & Variance \\
\hline Customers always say positive things about the products and services & 3.888 & 1.0512 & 1.105 \\
\hline Customers would always recommend their bank to any other person & 4.005 & 1.0878 & 1.183 \\
\hline $\begin{array}{l}\text { Customers often tell their friends and neighbours about the effectiveness' of } \\
\text { their bank in executing online banking services. }\end{array}$ & 3.902 & 1.0960 & 1.201 \\
\hline Customers encourage relatives and friends to do business with their bank' & 3.900 & 1.1138 & 1.240 \\
\hline Referral (RFTM) & 3.9265 & .99115 & .982 \\
\hline
\end{tabular}

\section{Source: Computer Result 2021}

Referral construct was measured using four questionnaire items which were developed on a five point Likert scale. The item labels are shown above. The mean of the four items was calculated to obtain the overall mean response on the referral construct (RFTM). The overall mean response on the items (3.93) shows that the customer's referral on their banks electronic platform is judged fairly good. The customers do not always say positive things about the products and services (3.89).

Table 5: Mean and Standard Deviation of Responses on Customer Support Items

\begin{tabular}{|l|r|r|r|}
\hline Items & Mean & $\begin{array}{r}\text { Std. } \\
\text { Deviation }\end{array}$ & Variance \\
\hline Bank website usually gives personal attention to customers & 3.515 & 1.0377 & 1.077 \\
\hline $\begin{array}{l}\text { Bank e-service web enables the firm customers to perform online transactions } \\
\text { to meet their needs }\end{array}$ & 3.946 & .9750 & .951 \\
\hline \begin{tabular}{l|r} 
Bank e-service website is suitable for the specific needs of their customers \\
Bank administrators of our online banking platform tell you exactly when the \\
services will be performed
\end{tabular} & 3.840 & .9921 & .984 \\
\hline Customer Support (CSTM) & $\mathbf{3 . 6 7 5 3}$ & 1.2105 & 1.465 \\
\hline
\end{tabular}

\section{Source: Computer Result 2021}

Customer support was measured using four questionnaire items which were developed on a five point Likert scale. The item labels are shown above. The mean of the four items was calculated to obtain the overall mean response on the customer support construct (CSTM). The overall mean response on the items (3.67) shows that the support the customers receive from the banks in the use of their electronic platform is fairly good.

\section{Testing of Hypotheses}

The hypotheses stated in this study were tested statistically in this section using Spearman Rank Order Correlation Coefficient. The result of the statistical testing was used to either accept or reject the null hypothesis formulated at 0.05 level of significance.

Table 6: Spearman Rank Correlation between customization and repurchase intention of deposit money banks in Nigeria

\section{Correlations}

\begin{tabular}{|c|c|c|c|c|}
\hline & & & Customization & Repurchase Intention \\
\hline \multirow{6}{*}{ Spearman's rho } & & Correlation Coefficient & 1.000 & $.770^{* *}$ \\
\hline & Customization & Sig. (2-tailed) & & .000 \\
\hline & & $\mathrm{N}$ & 366 & 366 \\
\hline & \multirow{3}{*}{ Repurchase Intention } & Correlation Coefficient & $.770^{* *}$ & 1.000 \\
\hline & & Sig. (2-tailed) & .000 & \\
\hline & & $\mathrm{N}$ & 366 & 366 \\
\hline
\end{tabular}

**. Correlation is significant at the 0.01 level (2-tailed).

From table 6 , the correlation coefficient $(\mathrm{r}=0.770)$ between customization and repurchase intention of deposit money banks is strong and positive. The coefficient of determination $\left(r^{2}=0.59\right)$ indicates that $59 \%$ change in repurchase intention of deposit money banks can be explained by customization. The significant value of 0.000 $(\mathrm{p}<0.01)$ reveals a significant relationship. Based on that, the null hypothesis was rejected. Therefore, there is a significant relationship between customization and repurchase intention of deposit money banks in Nigeria. 
Table 7: Spearman Rank Correlation between customization and referral of deposit money banks in Nigeria Correlations

\begin{tabular}{|c|c|c|c|c|}
\hline & & & Customization & Referral \\
\hline \multirow{6}{*}{ Spearman's rho } & \multirow{3}{*}{ Customization } & Correlation Coefficient & 1.000 & $.855^{* *}$ \\
\hline & & Sig. (2-tailed) & & .000 \\
\hline & & $\mathrm{N}$ & 366 & 366 \\
\hline & \multirow{3}{*}{ Referral } & Correlation Coefficient & $.855^{* *}$ & 1.000 \\
\hline & & Sig. (2-tailed) & .000 & \\
\hline & & $\mathrm{N}$ & 366 & 366 \\
\hline
\end{tabular}

**. Correlation is significant at the 0.01 level (2-tailed).

From table 7 , the correlation coefficient $(\mathrm{r}=0.855)$ between customization and referral of deposit money banks is strong and positive. The coefficient of determination $\left(\mathrm{r}^{2}=0.73\right)$ indicates that $73 \%$ change in referral of deposit money banks can be explained by customization. The significant value of $0.000(\mathrm{p}<0.01)$ reveals a significant relationship. Based on that, the null hypothesis was rejected. Therefore, there is a significant relationship between customization and referral of deposit money banks in Nigeria.

Table 8: Spearman Rank Correlation between customer support and repurchase intention of deposit money banks in Nigeria

\section{Correlations}

\begin{tabular}{|c|c|c|c|c|}
\hline & & & Customer Support & Repurchase Intention \\
\hline \multirow{6}{*}{ Spearman's rho } & & Correlation Coefficient & 1.000 & $.805^{* *}$ \\
\hline & Customer Support & Sig. (2-tailed) & & .000 \\
\hline & & $\mathrm{N}$ & 366 & 366 \\
\hline & & Correlation Coefficient & $.805^{* *}$ & 1.000 \\
\hline & Repurchase Intention & Sig. (2-tailed) & .000 & \\
\hline & & $\mathrm{N}$ & 366 & 366 \\
\hline
\end{tabular}

**. Correlation is significant at the 0.01 level (2-tailed).

From table 8 , the correlation coefficient $(\mathrm{r}=0.805)$ between customer support and repurchase intention of deposit money banks is strong and positive. The coefficient of determination $\left(\mathrm{r}^{2}=0.65\right)$ indicates that $65 \%$ change in repurchase intention of deposit money banks can be explained by customer support. The significant value of $0.000(\mathrm{p}<0.01)$ reveals a significant relationship. Based on that, the null hypothesis was rejected. Therefore, there is a significant relationship between customer support and repurchase intention of deposit money banks in Nigeria. Table 9: Spearman Rank Correlation between customer support and referral of deposit money banks in Nigeria

Correlations

\begin{tabular}{|lll|r|r|}
\hline & & Customer Support & \multicolumn{1}{c|}{ Referral } \\
\hline & & Correlation Coefficient & 1.000 & $.743^{* *}$ \\
& Customer Support & Sig. (2-tailed) &. & .000 \\
Spearman's rho & & $\mathrm{N}$ & 366 & 366 \\
& & Correlation Coefficient & $.743^{* *}$ & 1.000 \\
& \multirow{2}{*}{ Referral } & Sig. (2-tailed) & .000 &. \\
& & $\mathrm{~N}$ & 366 & 366 \\
\hline
\end{tabular}

**. Correlation is significant at the 0.01 level (2-tailed).

From table 9, the correlation coefficient $(r=0.743)$ between customer support and referral of deposit money banks is strong and positive. The coefficient of determination $\left(\mathrm{r}^{2}=0.55\right)$ indicates that $55 \%$ change in referral of deposit money banks can be explained by customer support. The significant value of $0.000(\mathrm{p}<0.01)$ reveals a significant relationship. Based on that, the null hypothesis was rejected. Therefore, there is a significant relationship between customer support and referral of deposit money banks in Nigeria.

\section{Discussion of Findings and Implications}

\section{Customization and Customer Satisfaction}

The findings revealed a significant relationship between customization and customer satisfaction. This was validated by the fact that website of their bank gives personal attention to them, through the e-service platform of their bank, they are able to carry out e-banking activities in ways that meets their needs, their bank's e-service website usually shows an understanding of their specific needs and they are satisfied with their bank's e-service channels if it allows them to perform online transactions without difficulties. Through customisation, products or 
services inherit a personal character for the customer; the emotional bond is, therefore, stronger (hi, 2012). The assumption is that customized products increase satisfaction and thus indirectly also loyalty, i.e. repurchasing behaviour. Furthermore, it has been discovered that personalised offers correlate with a higher level of satisfaction as well as an increased customer loyalty (Bock, Mangus\& Garretson Folse, 2016; Coelho \&Henseler, 2012). By implication, the higher the customisation of products, the more satisfy a customer is.

\section{Customer Support and Customer Satisfaction}

The findings revealed a significant relationship between customer support and customer satisfaction. This was validated by the fact that their bank website usually gives personal attention to them, their bank's e-service web enables them to perform online transactions to meet their needs, their bank's e-service website is suitable for their specific needs and their bank administrators of online banking platform tells them exactly when the services will be performed. Bowen and Chen (2001) opined that extremely customer support and consequent satisfaction leads to customer loyalty. Thus, delighted customers are less prone to offers from competition (Fornell, 1992). Similarly, Anton (1996) asserted that "customer support is usually prone to satisfaction and satisfaction is positively associated with repurchase intentions and the likelihood to recommend a product or service offering. These assertions all agree with the findings of the present study. This implies that when customers are not satisfied with the service or product support offering they leave the company. Through positive customer support, customer needs and wants are fulfilled, thereby bringing about satisfaction and retention. Also, by firm's continuous support to customers, they retain their old customers, which is instrumental to getting new customers.

\section{Conclusion}

From the findings of the study, the conclusion is reached. In this case, the study been able to provide the knowledge base that when the quality of e-service is improved in deposit money banks; it increases customer satisfaction. Also, the research has verified that customization and customer support can increase customer satisfaction among bank customers. Furthermore, the level of awareness towards the importance and benefits of internet will encourage e-banking among customers, retention and satisfaction.

\section{Recommendations}

Based on the conclusion of this study, the following are recommended;

1. Deposit money banks should develop their websites, by making it more interactive and simply, as this will encourage more patronage.

2. Online banking should be made easier for customers to make use of. The websites should be developed to suit individual needs

3. More awareness and sensitization programmes should be given to customers on the need for e-service banking. The benefits should be emphasized continuously.

4. Banks should make their websites more secured to encourage larger patronage and customer satisfaction

\section{References}

Abdul, S. (2014). Examiningthe impact of perceived service quality dimensions on repurchase intentions and word of mouth: A case from software industry of Pakistan. Journal of Business and Management, 16(1), 37-41.

Al - Maghrabi,T., Dennis,C., Halliday,S.V., \&Ali,A. (2011). Determinants of customer continuance intention of online shopping. International Journal of Business Science and Applied Management,6(1), 41-65.

Anderson, R.E, \& Srinivasan, S.S (2003). E-satisfaction and e-loyalty: A contingency framework, Psychology and Marketing, 20(2), 23-38.

Anderson, E. W., Fornell, C., \& Rust, R. T., (1997). Customer satisfaction, productivityandprofitability: Differences between goods and services. Marketing Science, 16(2) $129-145$.

Athaide, G. A., Meyers, P.W., \& Wilemon, D.L. (1996). Seller-buyer interactions during the commercialisation of technological process innovations. Journal of Product Innovation Management, 13(5),406-21.

Argyriou, E. (2012). Consumer intentions to revisit online retailers: A mental imagery account. Psychology \& Marketing, 29(1), 25-35.

Bock, D.E., Mangus, S.M.,\& Garretson Folse, J.A. (2016). The road to customer loyalty paved with service customisation. J of Business Research,69, 3923-3932.

Bolton, R.N., Kannan, P.K., \&Bramlett, M.D. (2000).Implications of loyalty program membership and service experiences for customer retention and value.Journal of the Academy of Marketing Science, 28(1), 95-108.

Burke,M.,\& Kraut, R. (2014). Growing closer on Facebook: Changes in tiestrength through social network site use.Proc. SIGCHI Conf.Human Factors Comput. Systems (CHI2014)(ACM, New York),4187-4196.

Buttle, F. A. (1998). Word-of-Mouth: Understanding and Managing Referral Marketing. Journal of Strategic Marketing, 6, 241-254.

Campbell, A. (2013). Word-of-mouth communication and percolationin social networks.Amer. Economy. 
Rev., 103(6), 2466-2498.

Campbell, J. (2015).Localised price promotions as a quality signal ina publicly observable network.Quant. Market Econom.,13(1), 27-57.

Cespedes, F.V. (1995).Concurrent marketing. Harvard Business School Press, Boston,MA, pp.243-66.

Chang, H., \& Wang, H. (2014). Evaluation of satisfaction and repurchase intention in online food group-buying, using Taiwan as an example, British Food Journal, 116(1), 44-61.

Chatterjee, K., \&Dutta, B. (2014). Credibility and strategic learning innetworks. Working paper, Pennsylvania State University, StateCollege.

Chiu, W.C., \&Solarek, S. (2009).Determinants of customer repurchase intention in online shopping.Online Information Review,33(4), 761-784.

Chu, S.C., \&Kim, Y. (2011).Determinants of consumer engagementin electronic word-of-mouth (eWOM) in social network sites.Internet. J. Advertising,30(1), 47-75.

Coelho, P., \&Henseler, J. (2012). Creating customer loyalty through service customisation.European $J$ of Marketing, 46(3/4), 331-356.

Collier, J.E., \&Bienstock, C.C. (2006). Measuring service quality in e-retailing.Journal of Service Research, 8(3), $260-75$.

Curran,J.M., \&Meuter, M.L. (2005). Self-service technology adoption: Comparing three technologies. Journal of Services Marketing, 19, 103-113.

Daily Graphic News (August 2008) www.ghheadlines.com/.../ daily graphic.

Edvardsson, B., Enquist, B., \&Johnston, R. (2005). Co-creating customer value through hyperreality in the prepurchase service experience.Journal of Service Research, 8 (2), 149-61.

Ehigie, B. O. (2006). Correlates of customer loyalty to their banks: A case study in Nigeria.International Journal of Bank Marketing, 24 (7), 494-508.

Eriksson, K., Kerem, K. \&Nilsson, D., (2005). Customer Acceptance of Internet Banking in Estonia. International Journal of Bank Marketing, 23(2), 200-216.

Fassnacht, M., \&Koese, I. (2006). Quality of electronic services: Conceptualizing and testing a hierarchical model. Journal of Service Research, 9, 19-37.

Fiore, A. M., Lee, S., \&Kunz, G. (2014). Individual differences motivations and willingness to use mass customisation option for fashion products. European Journal of Marketing, 38(7), 835-849

Fornell, C., Johnson, M.D., Anderson, E.W., Cha, J., \& Bryant, B.E. (1996). The American customer satisfaction index: nature, purpose, and findings. The Journal of Marketing, 60, 7-18.

Garcia, V.B., \&Winkelhues, K. (2016). The next revolution in mass customisation: An insight into the sneaker market. International Journal of Marketing, Communication and New Media. 4(6).

Goffin, K. (1994). Gaining a competitive advantagefrom support: Five case studies. European Services Industry, 1(4), 5-7.

Goffin, K. (1998). Customer support and new product development-an exploratorystudy.Journal of Product Innovation Management, 15(1),42-56.

Goffin, K., \& New, C. (2001). Customer support and new product development.International Journal of Operations \& Production Management, 21(3), 275-301.

Golan Telecom Annual Report (2013) www.cellcom.co.il.

He and Song (2008).A mediation model of tourists' repurchase intentions for packaged tour services, Journal of Travel Research, published online.

Hellier, P.K., Guersen, G.M., Carr, R.A., \& Richard, J.A. (2003). Customer repurchase intention: A general structural equation model.European Journal of Marketing, 37(11/12), 1762-1800.

Hennig-Thurau, T. (2004). Customer orientation of service employees. International Journal of Service Industry Management,15(5), 460-478.

Hill, N., \& Alexander,J. (2000). Handbook of customer satisfaction and loyalty measurement ( $3^{\text {rd }}$ ed.). Hampshire, England: Gower Publishing.

Ho, C.I., \& Lee, Y.L. (2007).The development of an e-travel service quality scale. Tourism Management, 28, 1434-1449.

Hume, M., Mort, G.S., \&Winzar (2010). The consequence of appraisal emotion, service quality, perceived value and customer satisfaction on repurchase intent in the performing arts. Journal of Services Marketing, 24(2), $170-182$

Idowu, P.A., Alu, A. O., \&Adagunodo, E.R.(2003). The effect of information technology on the growth of banking industry in Nigeria. The Electronic Journal on Information System in Developing Countries, 10(2), 1-8.

Jiang, P., \&Rosenbloom, B. (2005). Customer intention to return online: Priceperception, attribute-level performance, and satisfaction unfolding over time. European Journal of Marketing, 39(1/2), 150-174.

Kotler, P., \& Armstrong, G. (2011). Principle of marketing. $14^{\text {th }}$ Edition, Prentice Hall. Upper Saddle River.

Kuan, H.H., Bock,G.W., \&Vathanophas,V. (2008). Comparing the effects of website quality on customer initial 
purchase and continued purchase at e-commerce websites — Behaviour\& Information Technology, 27(1), 316.

Kuo, Y., Hu, T., \&Yang S.(2013).Effectsof inertia and satisfaction in female online shoppers on repeat-purchase intention: The moderating roles of word-of-mouth and alternative attraction. Managing Service Quality, 23(3), $168-187$.

Kumar, V.,\& Shah, D. (2004). Building and sustaining profitable customer loyalty for the 21 st century.Journal of Retailing, 80(4), 317-330.

La, K., \& Kandampully, J. (2002). Electronic retailing and distribution of services: Cyber intermediaries that serve customers and service providers. Managing Service Quality, 12, 100-116.

Lawless, M.W., \& Fisher, R.J. (1990).Sources of durable competitive advantage innew products.Journal of Product Innovation Management, 7(1), 35-44.

Li, H.Q., \& Hong, J. H. (2013). Factors influencing consumers online repurchasing behaviour: A review and research agenda. I-Business, 5(4), 161-166.

Lin, H. F., \& Lee, G. G. (2005). Customer perceptions of e-service quality in online shopping.International Journal of Retail and Distribution Management,33(2), 161-176.

Lovelock, C., \& Gummesson, E. (2004). Whither services marketing? In search of a newparadigm and fresh perspectives. Journal of Service Research, 7(1), 20-41.

Mittal, V., \& Kamakura, W.A. (2001). Satisfaction, repurchase intent, and repurchase behaviour: investigating the moderating effect of customer characteristics. Journal of Marketing Research, 38(1), 131-142.

Osagie L. U. \& Geraldine U. (2020). E-Service Quality and Customer Loyalty in Deposit Money Banks in Nigeria. European Journal of Business and Management, 12(21), 24-42

Osagie L. U., Justie O. N., \& Ezechirinum A. (2019). Information and Communication Technology Application and Service Quality of Federal Universities in Nigeria. British Journal of Marketing Studies, 7(5), 1-23

Parasuraman, A., Zeithaml,V.A., \& Berry, L.L. (1985). A conceptual model of service quality and its implications for future research. Journal of Marketing, 49, 41-50

Parasuraman, A., Zeithaml, V., \&Berry, L. (1988). SERVQUAL: A multi-item scale for measuring consumer perceptions of service quality. Journal of Retailing, 64(1), 12-40.

Pfeifer, P. (2005). The optimal ratio of acquisition and retention costs. Journalof Targeting, Measurement and Analysis for Marketing, 13(2), 179 -188.

Quick, M.J.,\& Burton, S. (2000). An investigation of the determinants of repurchase in a high involvement category, paper presented at the Australian \& New Zealand Marketing Academy Conference.

Roos, I., \&Edvardsson, B. (2008). Customer-support service in the relationship perspective.Managing Service Quality, 18(1),87-107.

Saleem and Rashid (2011).Relationship between customer satisfaction and mobile banking adoption in Pakistan. International Journal of Trade, Economics and Finance,2(6), 1-8

Sashi, C.M. (2012). Customer engagement, buyer-seller relationships, and social media. Management Decision, 50(2), 253-272.

Seiders, K., Glenn, B., Voss, D.G., \& Andrea, L.G. (2005). Do satisfied customers buy more? Examining moderating influences in a retailing context.Journal of Marketing,69(4), 26-43.

Scott, J. L (2002). Assessment of customer satisfaction in the banking industry. InternationalJournal of Marketing, $56(6), 135-157$

Sohn, C., \&Tadisina, S. K. (2008). Development of e-service quality measure for the Internet-based financial institutions.Total Quality Management \& Business Excellence, 19(9), 903-918.

Soteriou, A., \&Stavrinides, Y. (2000). An internal customer service quality dataenvelopment analysis model for bank branches. International Journal ofOperations, \& Production Management, 17 (7/8), 780-791.

Teas, R.K. (1993). Expectation performance evaluation and consumers perceptions of quality. Journal of Marketing, 57(4), 18-34.

Teresko, J. (1994). Service now a design element.Industry Week, 243(3),51-2.

Trusov, M., Buckling, R. E., \&Pauwels, K. (2009). Effectsof word of mouth versus traditional marketing: Findings from an internet social networking site. Journal of Marketing, 73, 90-102.

Wanke, M., \& Malte, F. (2004). The role of experiencein consumer decisions: Thecase study of brand loyalty, in T.Betsch, \&Haberstron, S. (Ed.). Theroutines of decision making, NJ: Lawrence Erlbaum Associates Publisher, Inc. pp.289-309.

Wolfinbarger, M., \&Gilly, M. (2003).Etailq: Dimensionalizing, measuring and predicting e-tail quality. Journal of Retailing, 79, 183-198.

Yang, Z., \& Jun, M. (2002). Consumer perception of e-service quality: From internet purchaser and no purchaser perspectives. Journal of Business Strategies, 19(1), 19-41.

Yasuharu, U. (2003). The Effects of Information System Investment in Banking Industry. JEL Classification, D24, G21, L86. 
Yousaf, A., \&Steene, A. (2011). The impact of ICT in the eyes of hotel managers (Cyprus), Masters Thesis, Department of Business Studies, Sodertorns University, Cyprus. sh.diva-Portal.org. 